\title{
STOCHASTIC FAIR VALUE: ATTRIBUTES AND APPLICATIONS
}

\author{
Justine Sophia Jaunzeme \\ Ventspils University of Applied Sciences, Latvia \\ justine.jaunzeme@venta.lv
}

\begin{abstract}
The International Financial Reporting Standards define the concept of assets' and liabilities' fair value. In the case of perfect competition market, the concept of fair value closely corresponds with the concept of the present value, paradigm of what was formulated by Irving Fisher: "The value of an asset always equals the future cash flow discounted at the opportunity cost of capital." Zvi Bodie and Robert C. Merton offered the term "fundamental value" in order to distinguish between the market value and theoretical value calculated as present value. In the case when cash flow associated with definite asset is stochastic, the fair value is stochastic too. The stochastic models spread in the scientific literature. But the author has not met the concept of the stochastic fair value in scientific literature intended for accounting. In current paper what is the part of the research "Holistic approach to the fair value concept and estimation" the investigation of the stochastic fair value concept, attributes and applications is provided. The expected fair value and standard deviation of fair value, and volatilities of these both indicators as the primary characteristics of fair value are offered. Theoretical constructions, discussion, conclusions and recommendations are oriented to the theoretical and practical implementations in order to get from sample survey more information for interpretations and decision making. The theoretical application presented in the current paper is connected with the well-known MM theorem of Franco Modigliani and Merton Miller: "The value of firm does not depend on firm's capital structure". It is proved that the MM theorem in case of the stochastic cash flows, generally speaking, does not hold. The practical application presented in the paper is connected with the fair value concept in the International Public Sector Accounting Standards. It is applied to the valuation of non-rivalrous free communal good.
\end{abstract}

Keywords: International Financial Reporting Standards, International Public Sector Accounting Standards, fair value, fundamental value, stochastic fair value.

\section{Introduction}

James C. Van Horne, John M. Vachowiz Jr. in the famous book "Fundamentals of Financial Management" [1] wrote: "The acceptance criterion for capital investments is perhaps the most difficult and controversial topic in finance." The International Financial Reporting Standards (in abbreviation IFRS) define the concept of assets' and liabilities' fair value. Generally speaking, the fair value is useful indicator in the acceptance criterion for capital investments. In this paper the concept of stochastic fair value is offered and attributes of the fair value of the stochastic benefit flow generated by the investment are investigated. As the fair value concept in accounting is professionally and holistically analysed, the genesis of the value concept and deepest economic essence have to be taken into account. The concept of good's value has an ancient history, it has been discussed already in the works of Aristotle. One of the most meaningful explanations of analysis of history of goods' value is found in the first chapter of Carl Marx's book "A Contribution to the Critique of Political Economy" [2]. Historically, a statement is widely recognized: "Every good reveals itself in two ways: value-in-use and value-in-exchange. The value-in-use is only in consumption, it is revealed only in the process of consumption. Value-inexchange first reveals itself only as a quantitative relationship, according to which values-in-use are exchanged." Professionally engaging in estimation of assets' fair value, the basic ideas of labour theory of value, which throughout centuries were promoted by economists and philosophers of various countries, are useful. Let us note that the Wassily Leontief input-output model allows theoretically demonstrate the basic assessments of the labour theory of value [3]. Indeed, if the very primary causes of wealth are searched for, William Petty, who imaginatively names labour as the father of wealth and land as the mother of wealth, is right. Later economists also consider physical capital as an important basic factor, though in essence it also is the result of land endowment and labour (in its broadest sense). "It is the opinion of the classic economic theory (Adam Smith, David Ricardo etc.), as well as Marxism, that the value of goods is determined by the amount of socially necessary labour embodied in their production (labour intensity)" [4].

In modern microeconomic theory consumer's preferences and behaviour, in the basic situation of which an economic subject exchanges some amount of good owned by himself to certain amount of other good not owned by this subject, is one of the fundamental topics. Historically, property rights provided a foundation for exchange transactions. The basis of the author's research is the generally 
accepted and authoritative definition of Alfred Marshall, cited from the book [5] "Principles of Economics"; Book II, Chapter II: Wealth":

"The value, that is the exchange value, of one thing in terms of another at any place and time, is the amount of that second thing which can be got there and then in exchange for the first. Thus, the term value is relative, and expresses the relation between two things at a particular place and time."

The main principles in economics are optimality and equilibrium. Each agent of market chooses such strategy (plan for action) to reach maximum utility. The approach of Alfred Marshall differs from the approaches of other researchers of value. It does not matter for what reason the subject wishes to exchange the goods - as desired value-in-use or value-in-exchange. It is possible that the subject has other consideration. It is important to affirm that subject wishes to engage in exchange transactions, if as a result of exchange the subject will increase his utility. Therefore, the theory of economics in the process of goods' exchange as most important factors distinguish the agents' internal subjective wish to exchange and external objective constraints to satisfy their wish at maximum. Subject maximizes his internal utility under the conditions of external constraints. Mathematical instruments are preferences which are modelled by utility function, constraints and budget set (Debreu, Gérard. The theory of value: an axiomatic analysis of economic equilibrium) [6]. By analysing the economic substance of asset's market value, John Maynard Keynes bestowed a significant role to the liquidity premium. As asset is being evaluated, market participants' notions about the asset's liquidity influence their preferences for this asset.

At the centre of the current research lies the concept of assets' and liabilities' fair value, what is encountered in the International Financial Reporting Standards (in abbreviation - IFRS) [7] and International Public Sector Accounting Standards (in abbreviation - IPSAS) [8]. According to IPSAS, fair value is an alternative measurement base for property, plant and equipment and intangible assets. IPSAS are applied by state and municipal institutions in the preparation of their financial statements. The author argues that it is very important that state and municipal institutions apply fair value measurement for their assets, since the production of their assets is financed by taxpayers' money.

The author believes that the research presented in this paper will benefit the international community of accountants and scientists.

\section{Materials and Methods}

International Financial Reporting Standards (in abbreviation - IFRS) [9] are set by International Accounting Standards Board (in abbreviation - IASB). The IASB is an independent, private-sector body. The mission of IASB is to develop IFRS standards that bring transparency, accountability and efficiency to financial markets around the world. The IASB was formed in 2001 as a successor of International Accounting Standards Committee (in abbreviation - IASC). The history of IASC, in turn, dates back to 1973, when it was formed by professional accounting bodies of Australia, Canada, France, Germany, Japan, Mexico, the Netherlands, the United Kingdom and the United States. The International Accounting Standards Board (IASB) considers fair value to be the most relevant measurement basis and requires a substantial portion of assets and liabilities to be measured at fair value on the balance sheet and gains or losses determined by reference to changes in assets and liabilities to be recognized in the income statement.

Definition 1. (The International Financial Reporting Standards 13 "Fair Value Measurement"). Fair value is defined as the price that would be received to sell an asset or paid to transfer a liability in an orderly transaction between market participants at the measurement date [7].

The U.S. financial accounting standards are set by the U.S. Financial Accounting Standards Board (in abbreviation - FASB) [10]. Founded in 1973, FASB is an independent, private-sector, not-for-profit organization, that establishes financial accounting and reporting standards for companies that follow the U.S. Generally Accepted Accounting Principles (in abbreviation - GAAP). The FASB is recognized by the U.S. Securities and Exchange Commission as the designated accounting standard setter for public companies.

As a result of convergence between the IFRS and the U.S. GAAP, disparities between fair value definitions found in IFRS 13 "Fair Value Measurement" and the U.S. FASB standard ASC 820 "Fair Value Measurements and Disclosures" have been minimized. In comparison to the IFRS, the U.S. FASB 
standard ASC 820 "Fair Value Measurements and Disclosures" provides a more extensive definition of fair value.

Definition 2. (the U.S. Financial Accounting Standards Board: standard ASC 820 "Fair Value Measurements and Disclosures".) Fair value is the price that would be received to sell an asset or paid to transfer a liability in an orderly transaction in the principal (or most advantageous) market at the measurement date under current market conditions (that is, an exit price) regardless of whether that price is directly observable or estimated using another valuation technique [9].

The important role in the fair value holistic research plays the fair value concept defined in the International Public Sector Accounting Standards (in abbreviation - IPSAS) [8]. According to these standards, fair value is an alternative measurement base for property, plant and equipment and intangible assets. Also instructions for application of the fair value measurement are provided in IPSAS. IPSAS are applied by state and municipal institutions in the preparation of their financial statements.

Definition 3. (International Public Sector Accounting Standards.) IPSAS define fair value as the price that would be received to sell an asset or paid to transfer a liability in an orderly transaction between market participants at the measurement date [8].

In the provided holistic research of fair value concept and applications the author has taken the Alfred Marshall's definition and definitions of IFRS and U.S.FASB as a given basic initial point. Also instructions of IPSAS for fair value measurement for their assets in the state and municipal institutions are considered to be important.

The definitions of fair value emphasize that fair value is a market-based measurement, not an entityspecific measurement. When measuring fair value, an entity uses the assumptions that market participants would use when pricing the asset or liability under current market conditions, including assumptions about risk. An entity shall measure the fair value of an asset or a liability using the assumptions that market participants would use when pricing the asset or liability, assuming that market participants act in their economic best interest.

"The underlying idea behind the use of fair value as a measurement attribute is that fair value represents a market price. Market prices capture the consensus view of all market participants about asset's or liability's economic characteristics, including assumptions about cash flows, profit margins, and risk," J.P.Jones and S.D.Stanwick [11] write.

The author of classical capital theory is Irwing Fisher known for his work "The Nature of Capital and Income" [12]. Irving Fisher defines the stock of wealth, which exists at a given moment and which is capable of generating intertemporal benefits in the future, as capital. There is no need to delimit the concept of capital to particular types of wealth, since all items of wealth are productive and able to generate economic benefits in the future. If it is feasible to evaluate the economic benefits in terms of money, then the cash flow generated by the asset can be estimated. Irwing Fisher recognizes the value of an asset as the present value of the cash flows, which are expected to be generated by an asset. According to the Irving Fisher, "value today always equals future cash flow discounted at the opportunity cost of capital." The opportunity cost of capital, also known as market capitalization rate, is that rate of return, which the investor would receive from the best alternative investment project, if he would choose the best alternative project instead of the investment project being evaluated. Formula of Irving Fisher: "value today always equals future cash flow discounted at the opportunity cost of capital" is absolutely important for asset's fair value practical estimation.

However, the formula of Irving Fisher needs to be made more precise. Zvi Bodie and Robert C. Merton [13] offered the term "fundamental value" in order to distinguish the market value and the theoretical value calculated as the present value: Asset's fundamental value is the amount of money, which well-informed investors would pay for the asset under concern in the market of perfect competition.

It must be stressed that the market value of an asset and its fundamental value usually differ and exactly in such case, if the investor is able to recognize undervalued and overestimated assets, possibilities of arbitrage could arise.

The microeconomic analysis provided by the author allows to conclude that in the case of perfect competition market the concept of fair value closely corresponds with the concept of the fundamental 
value. In this case the fair value of an asset can be interpreted as its fundamental value. In the case of another institutional form of market, when, for example, market power of some subjects takes place or agents face sufficient transaction costs, or asymmetric information presents, the fundamental value of an asset remains an important indicator, but may sufficiently differ from the market price observed in the practise.

Asset's fundamental value has found applications in investment theory, business valuation, and real estate appraisal. Real interest rates, which form in financial market, determine the value an asset. In the simplest models, it is assumed that the capital market is a market of perfect competition. Under such assumption, the transactions costs do not exist, the alternative cost of capital is constant for all investors, and perfect liquidity exists. John M. Keynes in his notable book "General Theory of Employment, Interest and Money" published in 1936 treats interest rate as the most important economic indicator; by means of interest rate variations central banks may influence and regulate the state economy. In the case of state intervention, the conditions of perfect competition market do not hold [14].

The cash flow associated with definite investment as a rule is uncertain because of the factor of time. Therefore, the fundamental value is uncertain also. If cash flows are stochastic, the quantitative indicators mentioned above are random variables, and their probability distributions must be studied. As stochastic models are applied, uncertainty becomes measurable. The famous economist Frank Hyneman Knight denoted measurable uncertainty as risk [15]. Traditionally, risk of a stochastic variable is measured by its standard deviation.

The stochastic models spread in the scientific literature, for example, concerning fair values in pensions and insurance, or forecasting models for stress testing concerning banks' capital adequacy, financial fragility, and probability of default. Information about the latest research in the different areas is easily available. Let us make just some notes. The more active investigations are provided in the insurance, because modern solvency regulations for the insurance industry require insurance undertakings to apply a fair valuation of their assets and liabilities [16; 17]. H. Zhang, T. Leung and O. Hadjialidis in their paper "Stochastic modeling of drawdawn insurance" illustrate the impact of default risk on fair values of contracts in the insurance business [18] The fair valuation of mortgage insurance under stochastic default and interest rates seems interesting [19]. Hardaker, J, B. and co-authors in the paper [20] "Coping with risk in agriculture: applied decision analysis" investigate stochastic aspects in agriculture. Stochastic benefits flow appears also in valuation of public goods with the survey approaches [21], and in the models for human resource fair valuation.

However, let us stress that the concept of stochastic fair value does not appear in accounting literature available for the author. For example, neither IFRS, nor IPSAS provide the concept of stochastic fair value.

The purpose of this paper as the part of the author's research "Holistic approach to the fair value concept and estimation" [20] is to adopt the fair value concept defined in the International Financial Reporting Standards, in the U.S. Financial Accounting Standards Board and in the International Public Sector Accounting Standards to the stochastic case, to consider stochastic version of asset's fair value concept, to investigate the stochastic fair value attributes and applications.

The author argues that in order to capture the synergy between assets held for use in business operating activities (property, plant and equipment, intangible assets and biological assets) their fair value shall be estimated as value-in-use by discounting future cash flows that are expected from these assets' portfolio. The portfolio is formed from multiple financial or other assets. In current paper the concept of the stochastic fair value of a portfolio of assets is introduced. In opinion of the author, the portfolio fair value plays decisive role in the decisions of auctions' participants. In the public auctions we can observe that often the buyer has the plan to integrate the sold asset in the portfolio and therefore increasing the fair value of the offered asset. In the auctions, both the expected fair value and risk expressed in term of standard deviation of stochastic fair value of the portfolio are relevant criteria for decision-making.

Theoretical constructions, discussion, conclusions and recommendations are oriented to practical implementation. The first application is theoretical, it concerns the famous MM theorem of Franco Modigliani and Merton Miller about the leverage's role. It is shown that in case of the stochastic cash flows generated by the firm the MM theorem, generally speaking, does not hold. As the second 
application the stochastic fair value of non-rivalrous free communal good [22] as practical application is considered.

Let us consider stochastic cash flow $X=\left(X_{1}, X_{2}, \ldots, X_{n}\right)$, where $X_{1}, X_{2}, \ldots, X_{n}$ represent stochastic amounts of either incoming or outgoing cash flows occurring at moments of time $t=1,2, \ldots, n$. The amounts are measured in monetary terms, for, example, in Euro. Multi-dimensional probability distribution of the random vector $X$ is given.

Discount factor $v$ is related to annual rate of interest $i$. The form of the discount factor $v$ depends on the interest capitalization scheme. In order to connect the fundamental value concept with the fair value concept, the author recommends continuous capitalization of interest. If periodic interest rate equals $i$ and continuous interest capitalization is applied, then the discount factor equals $v=\exp (-i)$. In further analysis, the author will apply the discount vector $T:=\left(v^{1}, v^{2}, \ldots, v^{n}\right)$. Discount vector is denoted by letter $T$, since discounting is the most traditional method for quantitative evaluation of the influence which the time factor exerts on value.

The net present value of stochastic cash flow $X=\left(X_{1}, X_{2}, \ldots, X_{n}\right)$ is denoted by $N P V(X ; v)$, or shortly by $N P V(X)$. By means of the vectors' scalar multiplication, the net present value of stochastic cash flows is expressed in the form $N P V(X ; v):=T \cdot X$.

Due to linearity of the expected value operations, the expected net present value shall be calculated according to the following equation:

$$
E[N P V(X ; v)]=T \cdot E(X), \text { where } E(X):=\left(E\left(X_{1}\right), E\left(X_{2}\right), \ldots, E\left(X_{n}\right)\right)
$$

where $X$-cash flows,

$E(X)$ - expected cash flows;

$n$ - number of time periods;

$T$ - discount vector;

$v$ - discount factor;

$N P V$ - net present value;

$E[N P V(X ; v)]-$ expected net present value given discount factor $v$.

According to the definition and properties of variance, the variance of the net present value in the form of matrix multiplication is expressed by the following equation:

$$
D[N P V(X ; v)]=T \operatorname{Cov}(X, X) T^{T}
$$

where $T^{T}$ - transposed discount vector;

$T$ - discount vector;

$X$ - cash flows;

$D[N P V(X ; v)]$ - variance of cash flows' net present value given discount factor $v$.

$\operatorname{Cov}(X, X):=(\operatorname{Cov}(X k, X j))$ is the covariation $(n \times n)$-matrix between stochastic components' of the cash flow $X$.

Let us note that in the practise $\operatorname{Cov}(X, X)$ can be estimated with help of correlations between stochastic components of $X$.

The expected value $E[N P V(X)]$ and standard deviation $S D[N P V(X)]$ with respect to interest rate provide a notion of the expected net present value of stochastic cash flow $X$ and its risk respectively, and serve for the purposes of cash flows' $X=\left(X_{1}, X_{2}, \ldots, X_{n}\right)$ informative analysis. Utilizing two most important indictors characterizing the stochastic fair value, e.g., the expected net fair value $E[N P V(\mathrm{X} ; \mathrm{v})]$ and standard deviation of fair value $S D[N P V(X ; v)]$, we do not have to speak about streamline optimal investment decision but about bicriterial Pareto efficient decision, taken the expected fair value as a good, but the indicator of the investment risk (standard deviation) as bad.

The author regards also the duration of the stochastic cash flow $X$, volatility of the expected net present value $E[N P V(\mathrm{X} ; \mathrm{v})]$ and volatility of standard deviation of the net present value $S D[N P V(X ; v)]$ as useful indicators to enrich information for decision making.

Remark. The common practise observed in mass media and in the scientific publications as well is to publish solely the mean of the sample, but not to publish some other indicators characterizing this sample. Therefore, for example, according to the samples $(5,5,5,5)$ and $(1,1,1,9,9,9)$, as a rule it is 
reported that the mean for both samples equals 5. It is easy to be convinced about veracity of this assertion - it is enough simply to see the scientific articles in the current proceedings. It is deplorable and inadmissible in so called information era. That is why the author appeals to the wide range of scientists what use sample surveys to report at least the triple (count, mean, standard deviation). In case of our example, it looks like $(4,5,0$ and $(6,5,4)$. Let us stress that if the sample survey has been done, then there are no additional expenses to get and to publish the triple, but informative wealth increases sufficiently.

\section{Results and discussion}

Modigliani-Miller theorem in the case of stochastic cash flow. The influence of leverage on the value of firm is studied within the framework of classical works by F.Modigliani and M.H.Miller "The cost of capital, corporation finance and the theory of investment" published in 1958 and "Corporate income taxes and the cost of capital: a correction" published in 1963 [22; 23]. For the purpose of analysis, the author will consider indicators of stochastic income - the expected value, standard deviation and the coefficient of variation - as well as pose presumption of arbitrage possibilities in the market of perfect competition. It has been ascertained that if the investor is risk averse, and if the investment risk is measured by means of standard deviation of the earnings, then the conclusions drawn by F. Modigliani and M. H. Miller might not be valid. If the investor measures the investment risk by means of the profit coefficient of variation, then the validity of F. Modigliani's and M. H. Miller's conclusions is not questioned.

The surprising result of modern finance theory - MM theorem asserts that the value of the firm in the homogenous class of firm does not depend on its capital structure, but always depends on the firm's expected future earnings. The author of the current paper refers to the translation [17] "Модильяни Ф., Миллер М. Сколько стоит фирма? Теорема ММ". As the author has provided asset's fair value holistic studies, the work of MM under tittle "How does the firm cost?" has to be taken into account, that is because the author considers the work of F. Modigliani and M. H. Miller [17] already in the paper [25]. As theoretical application of stochastic cash flow concept the author offers some generalization of the Modigliani-Miller two theorems. It will be proved that in case of stochastic earnings the behaviour of investors may differ depending on individual attitude towards risk, and, generally speaking, MM theorem 1 might not hold. Concerning the MM theorem 2, it will be shown that utilizing of risk indicators sufficiently enriches the content of MM result.

The author takes as honour to recall the arguments of F. Modigliani and M. H. Miller.

Let us consider hypothetical companies which exist only for one year in order to avoid complexities associated with the classification of multi-dimensional probability distribution of earnings. For the purpose of analysis, the author will utilize indicators of stochastic income - the expected value, standard deviation and the coefficient of variation - as well as pose the presumption of arbitrage possibilities in the market of perfect competition. It has been ascertained that, if the investor is risk averse and if the investment risk is measured by means of standard deviation of the profit, then the conclusions drawn by F. Modigliani and M. H. Miller might not be valid. If the investor measures the investment risk by the profit coefficient of variation, then the validity of F. Modigliani's and M. H. Miller's conclusions is not questioned.

First, let us assume that all firms are divided on classes containing firms with the equivalent income, e.g., homogenous firms. The homogeneity means that by perfect competition equilibrium the present market value of one dollar earning after one year is equal for each firm. According to the present value concept of Irving Fisher, the present value of one dollar after one year equals the discount factor $v$. Therefore, the $1 / v$ represents the rate of capital return in this class of firms.

In order to construct an economic model, the author will assume that at the present moment of time it is expected that physical assets owned by the company shareholders in the future will generate the flow of earnings due to the owners of the company. The earnings are not determined and should be regarded as stochastic amount. The cash flow for extinguishment of debt is a cash flow with fixed payments determined in accordance with the loan contract. The source of corporate capital is the issuance of common stock or bonds (or other debt instrument). Financing of firms by issuance of debt 
instruments is defined as financial leverage. Financial leverage substantially improves the possibilities for constructive firm's financial management.

In accordance with the narrative explanation provided above at the first moment of time the value of firm's assets is determined as equal to:

$$
v:=s+d
$$

where $s$-present market value of firm's shares;

$d$-present market value of firm's debt instruments;

$v$ - present market value of firm's assets.

Let us note that value of firm's assets (or market value of the firm) is the value of all securities emitted from the firm.

Theorem 1. Modigliani-Miller [17, page 44]. Let $X_{j}$ be the stochastic earnings before interest and taxes for the $j$-th firm of the considered class of firms. Then $v_{j}=v E\left(X_{j}\right)$.

Proof. Let us consider two firms with corresponding market values: $v_{1}=s_{1}+0, v_{2}=s_{2}+d_{2}$.

Let expected income and standard deviation of the income for both firms be equal to:

$$
E\left(X_{1)}=E\left(X_{2}\right)=: \mu, S D\left(X_{1}\right)=S D\left(X_{2}\right)=: \sigma .\right.
$$

The MM proved that $v_{1}=v_{2}$. The proof is provided assuming the opposite $v_{1} \neq v_{2}$ and showed that such assumption leads to the possibilities of the arbitrage, but it contradicts to our assumption about perfect competition capital market.

(a) Let $v_{1}<v_{2}$. Assume that investor Mr. Adams owns the shares of 2 nd firm in the value $\alpha_{s_{2}}$ $(0<\alpha \leq 1)$. Stochastic income received by Adams is $A^{(2)}=\alpha\left(X_{2}-r d_{2}\right)$.

But let us assume that Adams sales his shares getting a sum of money $\alpha s_{2}$ and bought for the sum of money $\alpha\left(s_{2}+d_{2}\right)$ the shares of the 1 st firm. Here the sum $\alpha \mathrm{d}_{2}$ is the sum of the money borrowed by Adams guaranteed this loan trough shares of the 1st firm bought.

Therefore, the part of shares of the 1st firm owned by Adams is $\alpha\left(s_{2}+d_{2}\right) / s_{1}$ and the same part of stochastic earning $X_{1}$ corresponds to Adams. The stochastic income of Adams is

$$
A^{(1)}=\alpha\left[\left(s_{2}+d_{2}\right) / s_{1}\right] X_{1}-\alpha r d_{2}=\alpha\left(v_{2} / v_{1}\right) X_{1}-\alpha r d_{2} \text {. }
$$

Let us considerthe indicators which characterize the random amounts $A^{(2)}$ and $A^{(1)}$ :

- expected value $E\left[A^{(2)}\right]=E\left[\alpha\left(X_{2}-r d_{2}\right)\right]=\alpha\left(\mu-r d_{2}\right)$;

- standard deviation $S D\left[A^{(2)}\right]=S D\left[\alpha\left(X_{2}-r d_{2}\right)\right]=\alpha \sigma$;

- coefficient of variation $c \operatorname{Var}\left[A^{(2)}\right]=\sigma /\left(\mu-r d_{2}\right)$, assuming $\mu-r d_{2}>0$;

- expected value $E\left[A^{(1)}\right]=E\left[\alpha\left(v_{2} / v_{1}\right) X_{1}-\alpha r d_{2}\right]=\alpha\left[\left(v_{2} / v_{1}\right) \mu-r d_{2}\right]$;

- standard deviation $S D\left[A^{(1)}\right]=S D\left[\alpha\left(v_{2} / v_{1}\right) X_{1}-\alpha r d_{2}\right]=\alpha\left(v_{2} / v_{1}\right) \sigma$;

- coefficient of variation $c \operatorname{Var}\left[A^{(1)}\right]=\sigma\left(v_{2} / v_{1}\right) /\left[\left(v_{2} / v_{1}\right) \mu-r d_{2}\right]=\sigma /\left[\mu-\left(v_{1} / v_{2}\right) r d_{2}\right]$.

If $v_{1}<v_{2}$, then $v_{2} / v_{1}>1$ and, obviously,

$$
E\left[A^{(1)}\right]>E\left[A^{(2)}\right], S D\left[A^{(1)}\right]>S D\left[A^{(2)}\right], c \operatorname{Var}\left[A^{(1)}\right]<\operatorname{cVar}\left[A^{(2)}\right] .
$$

Taken in account inequality $E\left[A^{(1)}\right]>E\left[A^{(2)}\right]$, MM conclude that in case $v_{1}<v_{2}$ owners of the 1 st firm shares are able to realize the arbitrage. But the arbitrage in perfect competition market is impossible. The contradiction proves that inequality $v_{1}<v_{2}$ is wrong. Thus $v_{1} \geq v_{2}$.

(a1) If the investor Adams compares the expected values and standard deviations of stochastic amounts $A^{(1)}, A^{(2)}$, then the decision of him depends on his attitude to the risk. There is not pure arbitrage, because additional expected earning is connected with risk increasing. This situation refers to the work of American economist Frank H. Knight "Risk, Uncertainty and Profit" [6]. The assertion of MM in this case may not fulfil.

(a2) If the investor measures the investment risk by the earnings coefficient of variation, then the validity of F. Modigliani's and M. H. Miller's conclusions is not questioned.

(b) Let $v_{1}>v_{2}$. Assume that investor Mr. Birch owns the shares of the 1st firm in the value $\alpha_{1}$ $(0<\alpha \leq 1)$. Because of $s_{1}=v_{1}$ the stochastic earnings received by Birch are $B^{(1)}=\alpha X_{1}$. 
Mr. Birch can sale his shares and utilize the received sum of money $\alpha \mathrm{s}_{1}$ for buying shares and bonds of the $2 \mathrm{nd} \mathrm{firm}$. Let Mr. Birch utilize the sum $\alpha \mathrm{s}_{1}$ in proportion correspondingly to the proportions shares and debt values in the assets of 2nd firm: $\alpha s_{1}=\left(s_{2} / v_{2}\right) \alpha s_{1}+\left(d_{2} / v_{2}\right) \alpha s_{1}$. Then the part of the 2nd firm's shares belonging to Mr. Birch is: $\left[\left(s_{2} / v_{2}\right) \alpha s_{1}\right] / s_{2}=\alpha s_{1} / v_{2}$.

The stochastic earnings of Mr. Birch are

$$
\begin{gathered}
B^{(2)}=\left(\alpha s_{1} / v_{2}\right)\left(X_{2}-r d_{2}\right)+\left(d_{2} / v_{2}\right) \alpha s_{1} r= \\
=\alpha s_{1}\left[\left(1 / v_{2}\right)\left(X_{2}-r d_{2}\right)+\left(d_{2} / v_{2}\right) r\right]=\alpha s_{1}\left[\left(1 / v_{2}\right) X_{2}-\left(1 / v_{2}\right) r d_{2}+\left(d_{2} / v_{2}\right) r\right]= \\
=\left(\alpha s_{1} / v_{2}\right) X_{2}=\alpha\left(v_{1} / v_{2}\right) X_{2} .
\end{gathered}
$$

Let us consider the indicators which characterize the random amounts $B^{(1)}=\alpha X_{1} ; B^{(2)}=\alpha\left(v_{1 /} v_{2}\right) X_{2}$.

- expected value $E\left[B^{(1)}\right]=E\left[\alpha X_{1}\right]=\alpha \mu$;

- standard deviation $S D\left[B^{(1)}\right]=S D\left[\alpha X_{1}\right]=\alpha \sigma$;

- coefficient of variation $c \operatorname{Var}\left[B^{(1)}\right]=\sigma / \mu$;

- expected value $E\left[B^{(2)}\right]=E\left[\alpha\left(v_{1 / v_{2}}\right) X_{2}\right]=\alpha\left(v_{1 / v_{2}}\right) \mu$;

- standard deviation $S D\left[B^{(2)}\right]=S D\left[\alpha\left(v_{1 / v_{2}}\right) X_{2}\right]=\alpha\left(v_{1 / v_{2}}\right) \sigma$;

- coefficient of variation $c \operatorname{Var}\left[B^{(2)}\right]=\sigma / \mu$.

If $v_{1}>v_{2}$, then $v_{1} / v_{2}>1$ and $E\left[B^{(2)}\right]>E\left[B^{(1)}\right], S D\left[B^{(2)}\right]>S D\left[B^{(1)}\right], c \operatorname{Var}\left[B^{(2)}\right]=c \operatorname{Var}\left[B^{(1)}\right]$. Taken in account inequality $E\left[B^{(2)}\right]>E\left[B^{(1)}\right]$, the MM conclude that in case $v_{1}>v_{2}$ owners of the 1st firm shares are able to realize the arbitrage. But the possibilities of the arbitrage in perfect competition market are impossible. This contradiction proves that inequality $v_{1}>v_{2}$ is wrong. Thus $v_{1} \leq v_{2}$.

(b1) If the investor Birch compares the expected values and standard deviations of stochastic amounts $B^{(1)}, B^{(2)}$, then the decision of him depends of his attitude to the risk. There is not pure arbitrage, because additional expected earning is connected with the increasing risk. The assertion of MM in this case may not fulfil.

(b2) If the investor measures risk by the earnings coefficient of variation, then the validity of F.Modigliani's and M. H. Miller's conclusions is not questioned.

In the prof of MM theorem the cases (a) and (b) together lead to the equality $v_{1}=v_{2}$.

Comment. In the opinion of the author, fundamental novelty of the Miller-Modigliani theorem's proof is the applications of the investors' behaviour and the concept of arbitrage. Let us note that MM consider the stochastic earnings of the firms and use in their proof the concept of expected earnings. But it is surprising that $\mathrm{MM}$ does not use the risk measuring indicators - standard deviation and the variation coefficient of stochastic earnings. The author of the current paper does not doubt that in case of stochastic cash flow it is absolutely necessary to take in account at least the simplest risk indicators. The second theorem of MM also confirms that assertion.

Theorem 2. Modigliani-Miller [17, page 47]. Let $\rho$ is the rate of capital return for the investments of the firm. Let $r$ is the interest rate of borrowed capital. Than the rate of capital return supported by leverage is $i=\rho+(\rho-r)(d / s)$, where $\mathrm{d}$ is the amount of debt, $\mathrm{s}$ is the stock - capital which belongs to the firm.

The author offers to consider the rate of capital return $\rho$ as stochastic. Then also the rate of capital return supported by leverage is stochastic: $i=\rho+(\rho-r)(d / s)=(1+d / s) \rho-r d / s$.

The indicators which characterize the random rate of capital return supported by leverage:

- $E(i)=(1+d / s) E(\rho)-r d / s$

- $S D(i)=(1+d / s) S D(\rho)=S D(\rho)+(d / s) S D(\rho)$.

Comment. Obviously, the last equation sufficiently enriches the MM theorem 2.

In order to construct an economic model, the author assumes that all physical assets are owned by shareholders. The source of corporate capital is the issuance of common stock or bonds (or other debt instrument). Financing of firms by issuance of debt instruments is defined as financial leverage. Financial leverage substantially improves the possibilities for constructive firm's financial management. 
But management must take in account that independently of interest rate $\mathrm{r}$ the leverage $d / s$ enlarges the risk of the firm.

Example of the stochastic fair value of non-rivalrous free communal good: "10 kilometres long cycle route in Ventspils". The second application is connected with the fair value concept defined in the International Public Sector Accounting Standards (IPSAS). According to these standards, the fair value is an alternative measurement base for property, plant and equipment and intangible assets. Also, instructions for application of the fair value measurement are provided in IPSAS [8]. IPSAS are applied by state and municipal institutions in the preparation of their financial statements. The fair value concept defined in the IPSAS in the paper [26] "Fair value of non-rivalrous free communal good: concept, estimation, and applications" has been adopted to the non-rivalrous free communal goods, which are financed by municipalities and government institutions from taxpayers' money and are set to develop a practically applicable and algorithmized non-rivalrous free communal goods' fair value estimation method based on technological, economical, financial, and social surveys. Non-rivalrous communal good is characterized by the concept "non-rivalrous" in the limited sense, which means that, if an individual consumes this benefit, the availability of this benefit to others will not be reduced but only for defined group of people. The concept "non-excludable", which means that no one can be excluded from the consumption of given good, is not the typical attribute of non-rivalrous communal good. In order to demonstrate practical application of non-rivalrous free communal good fair value investigation, the author applied the empirical example of Ventspils city municipal projects (Ventspils pilsētas pašvaldības projekti) "Development of cycling tourism in Ventspils city" presented in the paper [27]. The example has only illustrative character, therefore the author did not change anything in this example, for instance, the currency in LVL (Latvian lats) is left.

In addition to the content of thepublished paper the stochastic benefits flow generated by nonrivalrous free communal good is considered.

It is absolutely clear that the flow of benefits provided by non-rivalrous free communal good is stochastic and thereby the fair value of them also is stochastic. If municipality is going to choose some alternative investment project, the material of the presented paper would be recommended as a general line for sample investigation. In the current paper the example „Development of cycling tourism in Ventspils city" is utilized as a short illustrative example of stochastic non-rivalrous free communal goods' fair value estimation and as an example of investment diversification in the stochastic nonrivalrous free communal goods portfolio.

Since the paper [26] is easily available for the reader, let us describe the model shortly.

Within the project of cycling tourism development, 10 kilometres long cycle routes were built in Ventspils, connecting the international ferry terminal with popular objects of tourism in the city. Orderly infrastructure of cycling not only furthers the bicycle tourism, but also creates value-added to the offers of tourism and environment where it is located. The offered bicycle routes not only will allow for the city to be integrated in Euro Velo net, but also will further the mobility of Ventspils inhabitants. Total cost of the project is LVL 863379. The useful life of bicycle routes is estimated to be 10 years. According to estimates of the author, the number of potential users of bicycle routes is approximately 50000 people annually. As a result of surveys, the average ability to pay for the bicycle routes is EUR 20 per year. Total maintenance costs of the project are LVL 50000 annually.

In context of the current research let us note that it is absolutely necessary to consider the cash flow (willingness to pay) generated from the project as stochastic. Economical and social survey provided in order to justify the investment allows without increasing of the survey's cost at least approximately to estimate the mean and standard deviation of the stochastic yearly total willingness to pay. The estimation of the correlations between components of stochastic cash flow requires more rigorous and more expensive scientific research.

In order to illustrate the offered concepts, let us assume that the mean of annual stochastic total willingness to pay is 950000 and standard deviation is 900000 , but correlations between yearly components are zero. Then the expected value and standard deviation of the stochastic fair value of given non-rivalrous free communal good are

$$
E[P V(X ; i)]=950000\left(v^{1}+v^{2}+\ldots+v^{10}\right),
$$




$$
S D[P V(X ; i)]=900000\left(v^{2}+v^{4}+\ldots+v^{20}\right)^{0.5},
$$

where $v$-discount factor.

In the numerical calculations below the discount factor equals $v=\exp (-i)$.

In Table 1 the calculated information for decision making considering the project "Eurovelo in Ventspils city" is presented. In Figure 1 the graphs of functions $E[P V(i)], S D[P V(i)]$ are depicted.

\section{Calculated information for decision making considering the project "Eurovelo in Ventspils city"}

\begin{tabular}{|c|c|c|c|}
\hline $\boldsymbol{i}$ & $\boldsymbol{E}[\boldsymbol{P V}(\boldsymbol{i})], \mathbf{L V L}$ & $\boldsymbol{S D}[\boldsymbol{P V}(\boldsymbol{i})], \mathbf{L V L}$ & $\boldsymbol{c V a r}[\boldsymbol{P V}(\boldsymbol{i})]$ \\
\hline 0.00 & 9500000 & 2846050 & 0.2996 \\
\hline 0.02 & 8524473 & 2558005 & 0.3001 \\
\hline 0.04 & 7674345 & 2314194 & 0.3015 \\
\hline 0.06 & 6931644 & 2107031 & 0.3040 \\
\hline 0.08 & 6281137 & 1930229 & 0.3073 \\
\hline 0.10 & 5709891 & 1778586 & 0.3115 \\
\hline 0.12 & 5206917 & 1647812 & 0.3165 \\
\hline 0.14 & 4762859 & 1534372 & 0.3222 \\
\hline 0.16 & 4369745 & 1435362 & 0.3285 \\
\hline 0.18 & 4020772 & 1348396 & 0.3354 \\
\hline 0.20 & 3710123 & 1271520 & 0.3427 \\
\hline 0.22 & 3432820 & 1203130 & 0.3505 \\
\hline 0.24 & 3184592 & 1141909 & 0.3586 \\
\hline 0.26 & 2961775 & 1086777 & 0.3669 \\
\hline 0.28 & 2761214 & 1036842 & 0.3755 \\
\hline 0.30 & 2580190 & 991371 & 0.3842 \\
\hline
\end{tabular}

Code and Description:

- $\quad i$-interest rate as the time value of money in the financial market of perfect competition;

- $E[P V(i)]$ - expected fundamental value of total benefit fair value with respect to the interest rate $\mathrm{i}$;

- $S D[P V(i)]$ - standard deviation of the fundamental value of the total benefit fair value with respect to the interest rate $\mathrm{i}$;

- $c \operatorname{Var}[P V(i)]-$ coefficient of variation of the fundamental value of the total benefit fair value with respect to the interest rate $i$.

Let us note that relatively big coefficient of variation 0.9474 for annual stochastic total willingness to pay decreases sufficiently for the stochastic fundamental value of total benefit generated by the investment project lasting for 10 years. The calculations show that the coefficient of variation increases when the interest rate increases, because standard deviation decreases slower than the expected value decreases. This particular result of our example relates to the risk diversification idea and can be generalized in form of respective theorem.

The goal of the current paper is to appeal to municipalities to consider stochastic aspects of the social benefits provided through the investment projects and stochastic nature of non-rivalrous free communal good's fair value. 


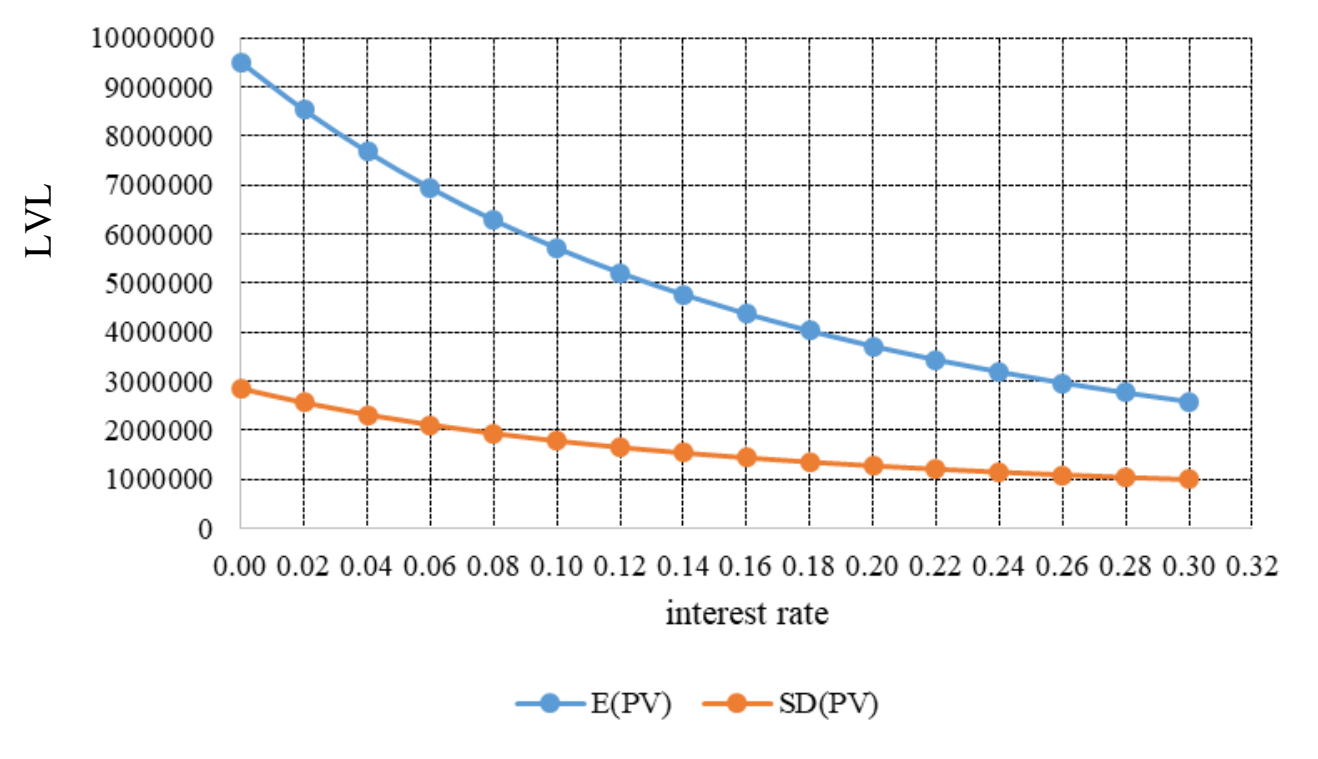

Fig. 1. Graphs of the expected fair value $E[P V(i)]$ and standard deviation of the fair value $S D[P V(i)]$ for total benefits provided by investment project "Eurovelo in Ventspils city"

\section{Conclusions}

1. The benefit flow associated with definite investment as a rule is uncertain because of the factor of time. Therefore, the fair value of the investment product is uncertain also. If the benefits flows are stochastic, the quantitative indicators of the fair value as a function of discount rate, such as the expected fair value and standard deviation of the fair value, must be studied. As stochastic models are applied, uncertainty becomes measurable and is denoted as risk. In opinion of the author, at least roughly the investigation of the stochastic character of the fair value sufficiently expands the information for decision making. To tell the truth, also almost all papers of the author mentioned in references can be enriched taking in account the stochastic character of the fair value.

2. Since the fair value of an asset estimation using Irving Fisher's paradigm is based on forecasts of the flow of benefits and the cost associated with definite investment, the investigation of the foreseen cash flow very often is provided with help of a sample survey. Therefore, descriptive statistics' indicators without additional expenses must been calculated. Assuming the expected net fair value as good and standard deviation of the fair value as bad, the decision maker makes bicriterial Pareto efficient decisions.

3. Theoretical constructions, discussion, conclusions and recommendations are oriented to practical implementation. The theoretical application concerns the famous MM theorem of Franco Modigliani and Merton Miller about the leverage's role in the firms' valuation. It is shown that in case of the stochastic cash flows generated by the firm the MM theorem, generally speaking, does not hold.

4. As the practical application the stochastic fair value of non-rivalrous free communal good is considered. The author recommends that the stochastic fair value be implemented in the International Financial Reporting Standards and the International Public Sector Accounting Standards. Both the expected value and standard deviation of the fair value should be reported in the financial statements.

\section{References}

[1] Van Horne J.C., Vachowiz Jr. J.M. Fundamentals of Financial Management. Eleventh Edition. "Prentice Hall", 2001.

[2] Marx C. A Contribution to the Critique of Political Economy. 1859. [online] [09.05.2021] Available at: https://www.marxists.org/archive/marx/works/1859/critique-pol-economy/.

[3] Leontief W. Input-Output Economics. Second Edition. - Oxford University Press. 1986, 436 pages.

[4] Economics' explanatory dictionary (Ekonomikas skaidrojošā vārdnīca). - Riga, Zinātne, 2000 (in Latvian). 
[5] Marshall A. Principles of Economics. - London: Macmillan and Co. 8th ed., 1920. [online] [09.05.2021] Available at: https://oll.libertyfund.org/title/marshall-principles-of-economics-8thed.

[6] Debreu G. The theory of value: an axiomatic analysis of economic equilibrium. New York: John Wiley \& Sons Inc., 1959.

[7] International Financial Reporting Standards (in abbreviation - IFRS). [online] [09.05.2021] Available at: https://www.ifrs.org/issued-standards/list-of-standards/

[8] Handbook of International Public Sector Accounting Pronouncements. I, II, III Edition. - New York: International Public Sector Accounting Standards Board, 2019. 2825 p.

[9] Financial Accounting Standards Board. U.S. FASB standard ASC 820 "Fair Value Measurements and Disclosures"- Norwalk, Co: FASB, 2011.

[10] U.S. Financial Accounting Standards Board (in abbreviation - FASB). [online] [09.05.2021] Available at: https://www.fasb.org/

[11] Jones J.P., Stanwick S.D. Fair value accounting: a guide to understanding the current standards. The Journal of Corporate Accounting and Finance/Autumn 1999, 1999, pp. 103-108.

[12] Fisher I. The Nature of Capital and Income. - New York: The Macmillan Company, 1906, 427 pages.

[13] Bodie Z., Merton R.C. Finance. - Prentice Hall, Pearson Education Company, 2000. 595 pages.

[14] Keynes J.M. General Theory of Employment, Interest and Money, 1936.

[15] Knight F.H.. Risk, Uncertainty and Profit. - London School of Economics and Political Science, 1933.

[16] Dhaene J., Stassen B., Barigou K., Linders D., Chen D. Fair valuation of insurance liabilities: merging actuarial judgement and market-consistency. - KU Leuven, Belgium, 2017.

[17] Smith A.D., Southall F.E. A Stochastic Asset Model for Fair Values in Pensions and Insurance. [online] [08.05.2021] Available at: www.ressources-actuarielles.net.

[18]Zhang H., Leung T., Hadjialidis O. Stochastic Modeling and Fair Value of Drawdown Insurance. Insurance Mathematics and Economics 53(3):840-850, 2013.

[19] Yang-Che \& Huang W., Yi-Ting \& Lin, Shih-Kuei \& Chuang, Ming-Che (2017). "Fair valuation of mortgage insurance under stochastic default and interest rates," The North American Journal of Economics and Finance, Elsevier, vol. 42(C), pages 433-447.

[20] Hardaker, J, B., author. Coping with risk in agriculture: applied decision analysis/J. B. Hardaker, G. Lien, J. R. Anderson, and R. B. M. Huirne. - Third edition. CAB International, 2015, 276 p.

[21] Brookshire S.D., Thayer M.A., Schulze W.D., d'Arge R.C. Valuing Public Goods: A Comparison of Survey and Hedonic Approaches. - The American Economic Review, Vol. 72, No. 1 (Mar., 1982), pp. 165-177.

[22] Modigliani F. and Miller M.H. The cost of capital, corporation finance and the theory of investment, 1958.

[23] Modigliani F. and Miller M.H. Corporate income taxes and the cost of capital: a correction, 1963.

[24] Modigliani F. and Miller M.H. How much does the firm cost? Theorem ММ (Сколько стоит фирма? Теорема MM) - Moscow: Delo, 2001, 272 pages.

[25] Jaunzeme J. The influence of leverege on the cost of firm (Влияние левериджа на стоимость фирмы). xxvii International scientific and practical conference "Economics and law: theory and practice" (19 January 2018). Scientific journal "Globus" - St.Petersburg, 2018, pp. 20-27.

[26] Jaunzeme J. Fair value of non-rivalrous free communal goods: concept, estimation, and applications. 18th International Scientific Conference "Engineering for Rural Development" Jelgava: LLU, 2020. pp. 249-262.

[27] Jaunzems A., Bolezina I, Norkuss N. Production of non-private goods and elimination of nonprivate bads in Ventspils city and Talsi disctrict (Neprivātu labumu ražošana un neprivātu launumu novēršana Ventspils pilsētā un Talsu novadā.) Book "Society and culture". Collection of theses, XVI - Liepaja: LiePA, 2014. pp. 518-532. 